\title{
The oyster proves the rule: mechanisms of pseudofeces transport and rejection on the mantle of Crassostrea virginica and C. gigas
}

\author{
Peter G. Beninger ${ }^{1, *}$, Anne Veniot ${ }^{2}$ \\ 'Laboratoire de Biologie Marine, Faculté des Sciences, Université de Nantes, 44322 Nantes, France \\ ${ }^{2}$ Département de Biologie, Université de Moncton, Moncton, New Brunswick E1A 3E9, Canada
}

\begin{abstract}
The pseudolamellibranch is the only main bivalve particle processing system whose mechanisms of pseudofeces rejection on the mantle have not been elucidated. To this end, the entire mantle surface and underlying tissue characteristics were investigated in the oysters Crassostrea virginica and C. gigas, using scanning electron microscopy and histology, as well as observations of particle transport on half-shell preparations. Pseudofeces transport is effected by short simple cilia atop specialized radial ridges, which extend from the gill-mantle junction near the adductor muscle to the mantle edges. The histology of the ridges is characterized by a densely-ciliated pseudostratified epithelium and numerous acid mucopolysaccharide (AMPS)-containing mucocytes, and differs markedly from that of the inter-ridge regions which present a cuboidal epithelium containing few mucocytes and isolated tufts of long simple cilia. In contrast to the pseudofeces transport (infrabranchial) region of the mantle, the suprabranchial mantle region is uniformly and densely ciliated, and devoid of ridges. The sparse ciliation of the inter-ridge region and the counter-current beat of the ridge cilia (presumably isolated to varying degrees from the pallial flow by the mucus-particle rafts involved in mucociliary transport) indicate that the maintenance of pallial flow is accomplished almost exclusively by the gill and the suprabranchial mantle ciliation in these 2 species. Pallial pseudofeces rejection mechanisms to date are summarized for the 4 main bivalve gill systems, which may be grouped into 3 categories: (1) pallial transport with vertical elevation accomplished via composite cilia (homorhabdic filibranchs and eulamellibranchs), (2) pallial transport with vertical elevation accomplished via mantle ridges (pseudolamellibranchs), and (3) voidance via valve clapping (heterorhabdic filibranchs).
\end{abstract}

KEY WORDS: OYster $\cdot$ Feeding $\cdot$ Mantle $\cdot$ Rejection $\cdot$ Pseudofeces

\section{INTRODUCTION}

The bivalve mantle accomplishes a variety of important functions, including shell formation, storage of energy reserves, and perception of external stimuli; in many species, reproductive tissue also extends into the mantle when gametes are ripe (see Peek \& Gabbott 1990, Beninger \& Le Pennec 1991). Most studies have focussed on these aspects of the mantle functions and their specific sites (e.g. Wilbur 1972, 1985, Waller 1976 , Saleuddin \& Petit 1983, Wilbur \& Saleuddin 1983), rather than on pseudofeces rejection (Wallengren 1905, Orton 1912, Kellogg 1915, Ansell 1961, Galtsoff 1964)

•E-mail: peter.beninger@svt.univ-nantes.fr
The process of pseudofeces transport on the mantle has recently been shown to involve both specialized mucus types and a specialized cilia type in bivalves possessing 3 of the 4 main gill types (Beninger \& St-Jean 1997b, Beninger et al. 1999); the fourth such gill type, the pseudolamellibrach, has not yet been investigated.

The presence of specialized cilia on the bivalve gill has long been known, although understanding of their functions is uneven (e.g. Atkins 1936, 1937a,b, 1938, Moore 1971, Owen 1974, 1978, Owen \& McCrae 1976, Ribelin \& Collier 1977, Jørgensen 1990, Silverman et al. 1996). In contrast, it was not until detailed cilia mapping was undertaken on the bivalve mantle that the presence of specialized cilia and their associated func- 
tion were reported on this pallial organ (Beninger et al. 1999). This procedure has allowed the identification of specific cilia types on distinct mantle tracts specialized in the transport of pseudofeces (Beninger et al. 1999). From this work it has emerged that, in bivalves possessing a ventral gill particle groove and siphons (the vast majority of species), specialized 'composite' cilia effect the vertical isolation of pseudofeces from the general ciliated mantle surface along a distinct mantle tract. This organization enables the process of pseudofeces rejection to occur simultaneously with, and independantly of, other pallial functions.

To this point, the limited available data (Beninger et al. 1999) suggest that the 3 bivalve gill types examined may be grouped into 2 main categories regarding pallial pseudofeces transport/rejection: Category 1 - those possessing a ventral particle groove on the gill, and siphons; this includes most homorhabdic filibranchs and all eulamellibranchs, i.e. the vast majority of bivalve species. The presence of a gill ventral particle groove as the only means of collecting and conveying particles trapped on the gill to the palps and mouth generally assigns pseudofeces production to the palps. With these organs being situated at the anterior extremity of the bivalve, a secure means of transporting the pseudofeces to the only unfused area of the mantle is required, i.e. the posterior region for ejection via the inhalent siphon. The members of this category possess specialized cilia and associated mantle tracts for pseudofeces transport and rejection.

Category 2-those in which a gill ventral particle groove and siphons are absent; only the Pectinidae have been studied to date, although allied families include the Limidae and Spondylidae. The members of this category expel pseudofeces from the mantle cavity entirely by valve clapping (Yonge 1967, Morton 1979), and hence possess no specialized ciliated mantle tracts for pseudofeces transport and rejection.

The fourth main bivalve gill type, represented by the pseudolamellibranch family Ostreidae, presents an intriguing combination of characteristics: dorsal and ventral gill particle grooves, but no siphons. It is therefore of interest to determine how such a system transports and expels pseudofeces from the mantle cavity, and whether this mechanism conforms to the general principles sketched out for the members of the other 2 categories. Observation of the behaviour of inert particles deposited on the bivalve mantle have been shown to be quite comparable to the treatment of pseudofeces on the mantle of intact specimens (Beninger \& St-Jean 1997b, Beninger et al. 1997a). Such observations by Galtsoff (1964) strongly suggest the existence of specialized ciliated tracts for pseudofeces transport and rejection. A more recent study on intact specimens showed that pseudofeces from the palp rejection site are deposited on mantle 'tracts', although neither the location and nature of these tracts nor the trajectories of pseudofeces on the mantle were specified (Ward et al. 1994).

The present manuscript investigates the mantle features and ciliation of 2 oyster species, Crassostrea virginica Gmelin, 1791 and Crassostrea gigas Thunberg, 1793, and relates this to pseudofeces transport and rejection, in order to more fully understand the fundamental principles of this important aspect of particle processing in bivalves.

\section{MATERIALS AND METHODS}

Specimen sampling and fixation. Specimens of Crassostrea virginica were collected from the Aldouane estuary, New Brunswick, Canada (46 $6^{\circ} 13^{\prime} \mathrm{N}, 64^{\circ} 29^{\prime} \mathrm{W}$ ), from 1996 to 1998, and specimens of Crassostrea gigas were collected from lease sites in Bourgneuf Bay, France $\left(46-47^{\circ} \mathrm{N}, 1-2^{\circ} \mathrm{W}\right)$ from 1997 to 1998 . The specimen size range for scanning electron microscope (SEM) observations was limited to 9 to $30 \mathrm{~mm}$ (dorsoventral shell axis), in order to fit whole individuals in the SEM specimen chamber. In the Iaboratory, the hinge was separated using a scalpel blade and the adductor muscles carefully sectioned, avoiding damage to the mantle lobes. Specimens destined for histological examination were fixed whole in aqueous Bouin's solution, while specimens for SEM were fixed whole in a hypertonic solution of cold $2.5 \%$ glutaraldehyde-sodium cacodylate buffer (Beninger et al. 1995a).

Specimen processing. Specimens for histological examination were cold-fixed for 24 to $48 \mathrm{~h}$, rinsed under running water for at least $12 \mathrm{~h}$, dehydrated in an ascending ethanol-Histoclear ${ }^{\mathrm{TM}}$ series, and embedded in paraffin for sectioning. Sections were set at $7 \mu \mathrm{m}$ for topographical histology, and at $10 \mu \mathrm{m}$ for mucocyte histochemistry (Beninger et al. 1993). Topographical sections were stained using the modified Masson's trichrome procedure (Beninger et al. 1995b), and sections for mucocyte histochemistry were stained using the periodic acid-Schiff (PAS)-alcian blue technique (Beninger et al. 1993, Beninger \& St-Jean 1997a,b).

Specimens for SEM observation were rinsed twice in cacodylate buffer, and partially dehydrated in an ascending ethanol series to $70 \%$ ethanol. At this point the tissue hardness facilitated the removal of the visceral mass using microsurgical instruments, to expose the entire mantle surface. The dissected specimen was further dehydrated to $100 \%$ spectroscopy-grade ethanol, critical-point dried in liquid 'bone-dry' $\mathrm{CO}_{2}$, placed on an SEM stub with silver paint, and sputter-coated with gold. Detailed SEM observations were performed on the entire mantle surface using a JEOL JSM 500, and 


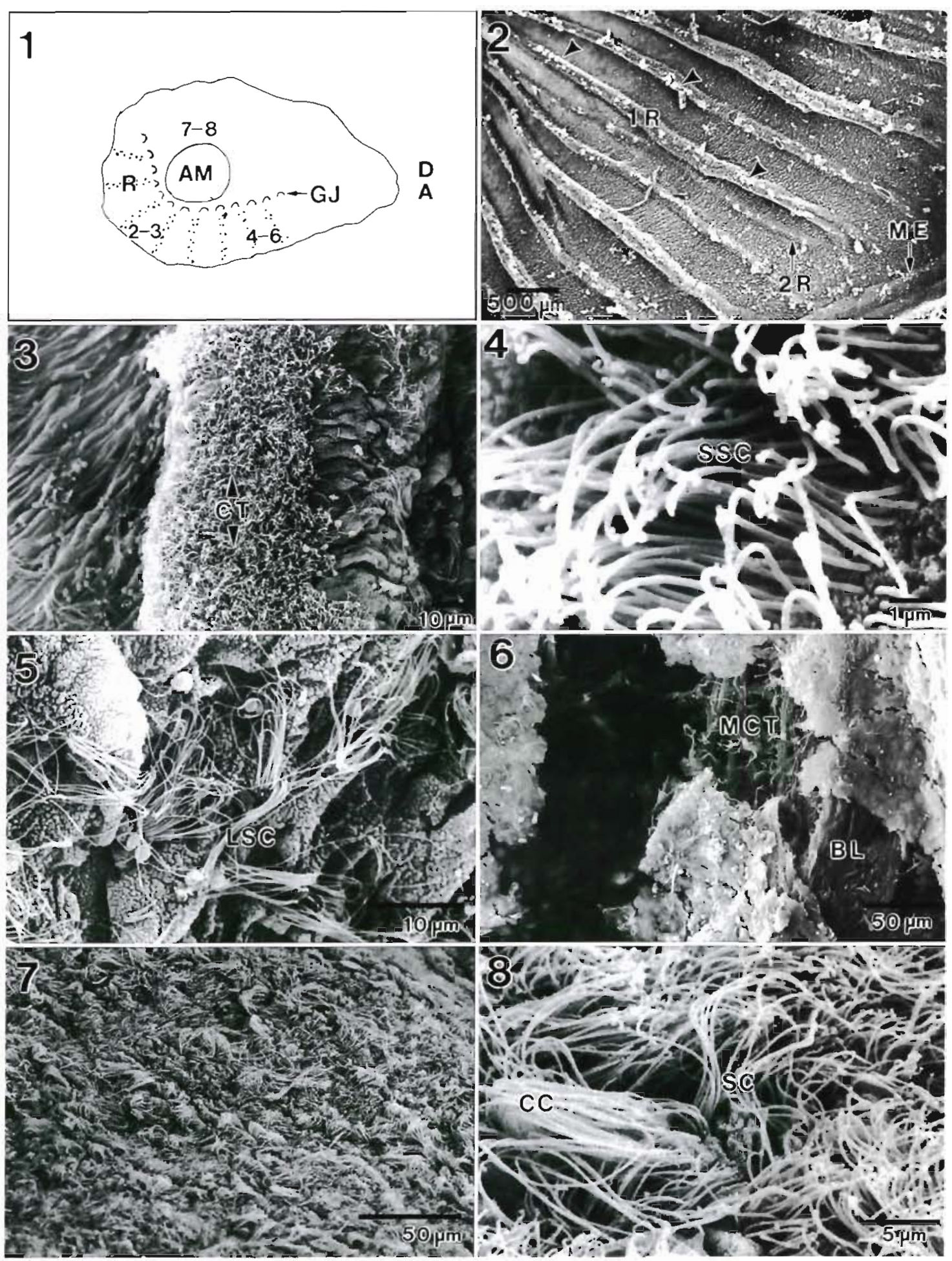

Fig. 1. Crassostrea virginica, scanning electron microscope (SEM) observations. (1.1) Schematic drawing showing location of mantle rejection ridges $(R)$ in relation to gill junction with the mantle (GJ) and adductor muscle (AM). Dorsal shell region (D) corresponds to anterior body region (A) in the Ostreidae. Numbers designate regions correponding to micrographs 1.2-1.8. (1.2) Low-power view of infrabranchial mantle surface, showing primary (1R) and secondary (2R) ridges. Note mucus-pseudofeces residues on ridges (arrowheads indicate examples), virtual absence of such residues in inter-ridge regions. ME: mantle edge. (1.3) Detail of ciliated tract (CT) on mantle rejection ridge. Note density of cilia at crest, compared to sparse ciliation on sides of ridge. (1.4) Detail of short simple cilia (SSC) on crest of rejection ridge. (1.5) Detail of sparse tufts of long simple cilia (LSC) on sides of ridge. (1.6) Preparation in which the rejection ridge was deliberately stressed after critical-point dying to reveal the underlying musculo-connective tissue (MCT) and basal lamina (BL). Most cilia are removed in the process. (1.7) Low-power micrograph of the mantle in the suprabranchial region. Note uniform ciliation, absence of ciliated ridges. (1.8) Detail of cilia in suprabranchial region. Short cilia (SC) predominate, with rare composite cilia (CC) 

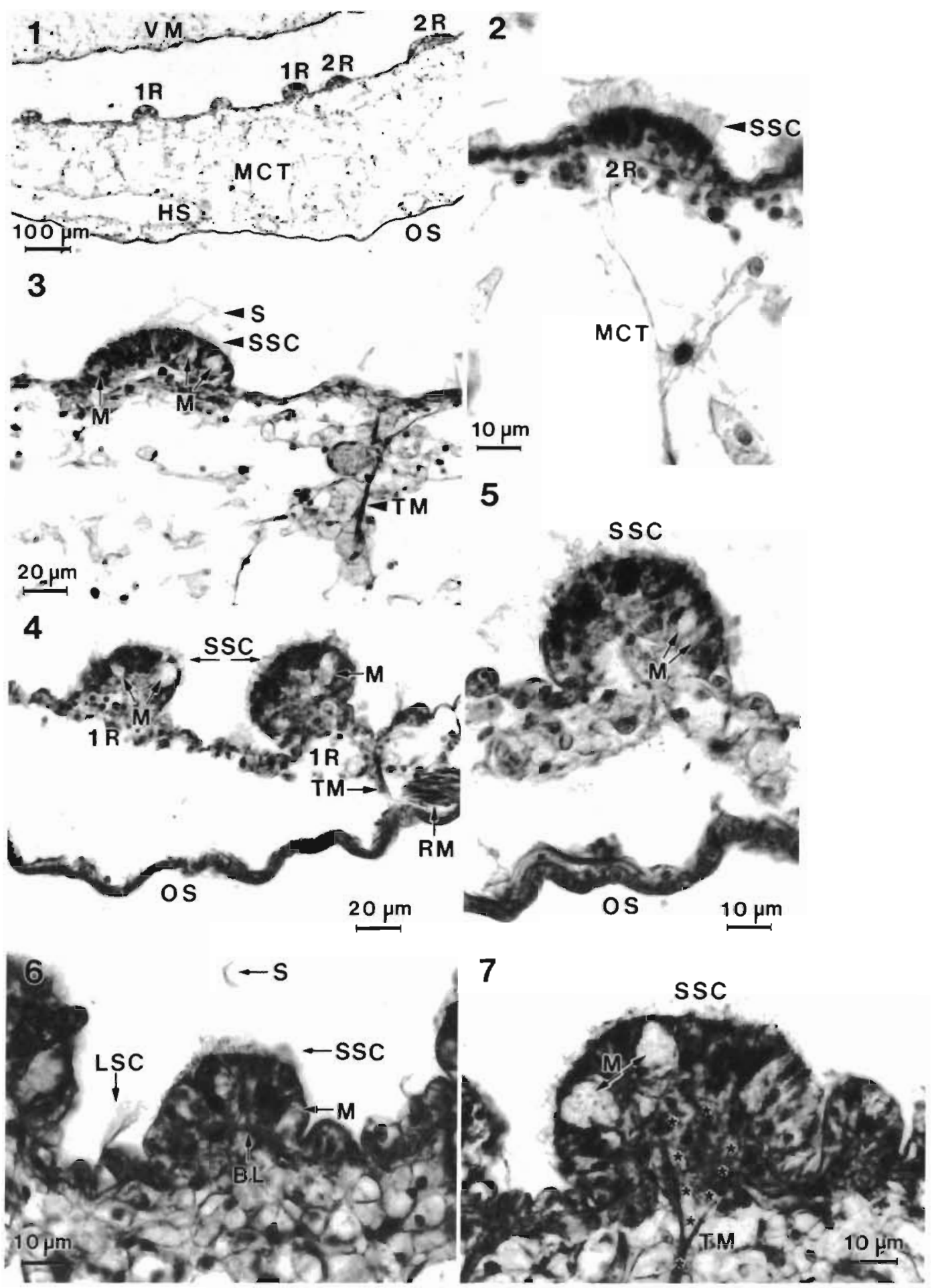

Fig. 2. Crassostrea gigas, histology of mantle rejection ridges. Paraffin sections, 7 um, modified Masson's trichrome stain (see Beninger et al. 1995b). (2.1) Low-power micrograph showing series of primary (1R) and secondary (2R) rejection ridges. HS: haemolymphatic sinus; MCT musculo-connective tissue; OS: outer (shell) surface of mantle; VM: visceral mass. (2.2) Detail of secondary ridge $(2 \mathrm{R})$, with short simple cilia (SSC) clearly visible on crest. MCT: musculo-connective tissue. (2.3-2.5) Primary ridges. Note presence of mucocytes (M) in every section, short simple cilia (SSC) on ridges, occasional presence of long putative 'sweeper' cilia (S). OS: outer (shell) surface of mantle; RM: radial muscle; TM: transverse muscle fibres. (2.6) Primary ridge showing 3 ciliary types: short simple cilia on ridge crest (SSC), long putative 'sweeper' cilia, and occasional tufts of long simple cilia (LSC) in inter-ridge region. BL: basal lamina; M: mucocyte. (2.7) Detail of primary ridge, showing insertion of transverse muscle fibre (TM, asterisks). M: mucocytes; SSC: short simple cilia 
recorded on both $\mathrm{Hi}-8$ videotape and $4 \times 5$ format Polaroid Land negatives.

Direct observation of particle transport on the mantle. Since particle transport on the bivalve mantle is identical in both half-shell and intact preparations (Beninger \& St-Jean 1997b, Beninger et al. 1997a), inert particles (suspensions of carmine and graphite in seawater) were deposited on the mantle surface near the sectioned adductor muscles of 2 half-shell preparations, and on the labial palps of 3 additional preparations (specimen size range 76 to $86 \mathrm{~mm}$ ). The ensuing particle distributions and trajectories were observed under a dissecting microcope, using a fibre-optic light source.

\section{RESULTS}

For the sake of consistency, the nomenclature of cilia types follows that presented in Beninger et al. (1999). Dimensions are as observed on processed tissue.

The mantle of Crassostrea virginica and $C$. gigas presented a series of radial ridges extending from the gill-mantle junction to the mantle edge (Fig. 1.1, 1.2). The ridges appeared to be specialized structures histologically, as they presented a pseudostratified epithelium, in contrast to the cuboidal epithelium of the interridge region (Fig. 2). The ridges differed in degree of prominence, with well-developed primary ridges and smaller secondary ridges visible in both SEM and histological micrographs (Figs. $1.2 \& 2.1$ ). This difference was also reflected in the histological appearance: pri- mary ridges were generally much more salient than secondary ridges (Fig. 2).

The crests of the mantle ridges presented a dense cover of short simple cilia (SSC) approx. $5 \mu \mathrm{m}$ in length (Figs. 1.3-1.4, 2.2-2.7, 3.1-3.2). Occasional tufts of long simple cilia (LSC) were also observed (Figs. 2.3, 2.6 \& 3.2), here termed 'sweeper' cilia (based on their presumed movement beneath the mucus-particle rafts). In contrast to Crassostrea gigas, in which the ridge ciliation was uniform, the sides of the ridges in $C$. virginica presented only isolated tufts of LSC (Fig. 1.3, 1.5); this was the only significant difference between the mantle characteristics of the 2 species. Well-developed mucocytes were present in the ridge epithelium, especially in the primary ridges (Fig. 1.3 to 1.7). Mucocytes which were filled with secretions contained only 1 category of secretion type: acid mucoplysaccharides (AMPS, Fig. 3). No mucocytes or portions of mucocytes showed any APS-positive staining stronger than the background stain (Fig. 3), indicating that no neutral NMPS were present. Some mucocytes were only partially filled with AMPS; these were interpreted as having either recently discharged the missing AMPS, or as having not yet completed filling the cell volume with AMPS (Fig. 3). The space between the outer (shell) pallial surface and the inner pallial surface was comprised of lacunar musculo-connective tissue (with large haemolymphatic sinuses), extending into the mantle ridges (Figs $1.6 \& 2.1-2.7$ ). Transverse muscle fibres spanned the lacunar musculo-connective tissue (Fig. 2.3, 2.4), entering the ridges at intervals and lining the underside of the basal lamina (Fig. 2.7).
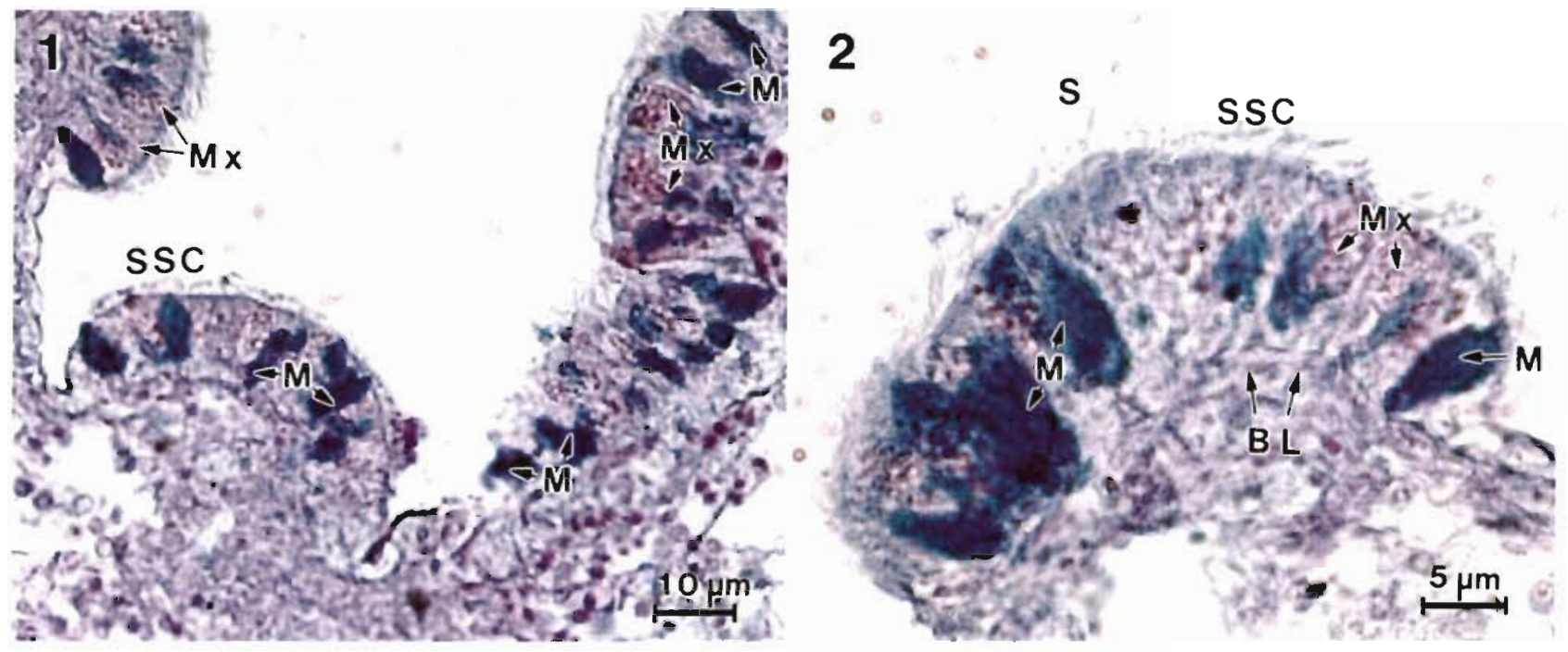

Fig. 3. Crassostrea gigas, paraffin sections, PAS-Alcian blue staining protocol. (3.1) Four ridges showing ubiquity of AMPS mucocytes (M). Mx, mucocytes partially filled with AMPS, either after discharge or in early stage of elaboration of AMPS. (3.2) Detail of primary ridge, showing AMPS mucocytes (M), short simple cilia (SSC), and putative 'sweeper' cilia. BL: basal lamina; Mx: mucocytes partially filled with AMPS, either after discharge or in early stage of elaboration of AMPS 


\section{Category 1}

$1 \mathrm{~A}$

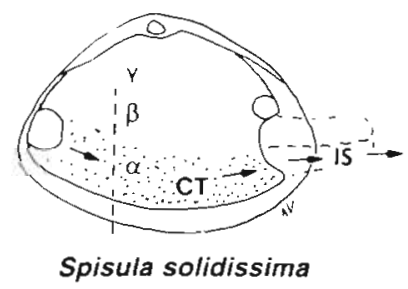

$2 \mathrm{~A}$

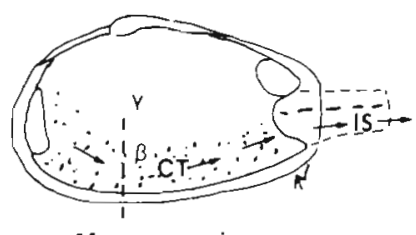

Mya arenaria

$3 \mathrm{~A}$

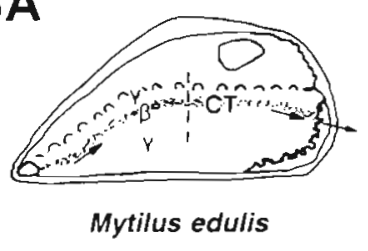

Category 2

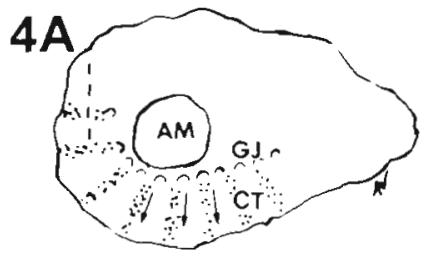

Crassostrea virginica
1B

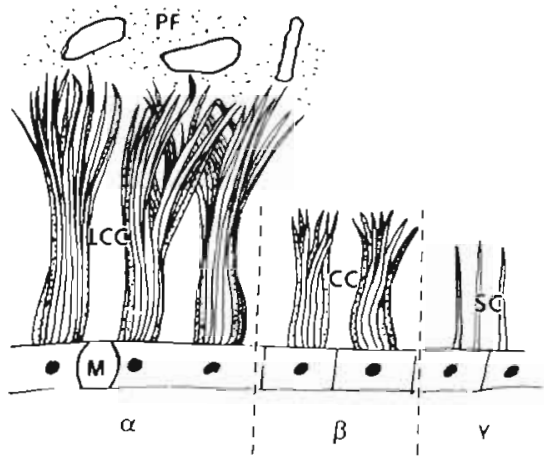

2B

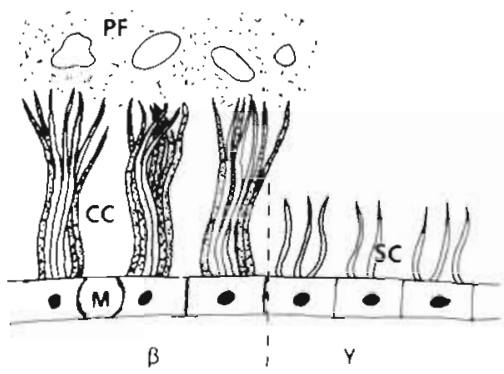

3B
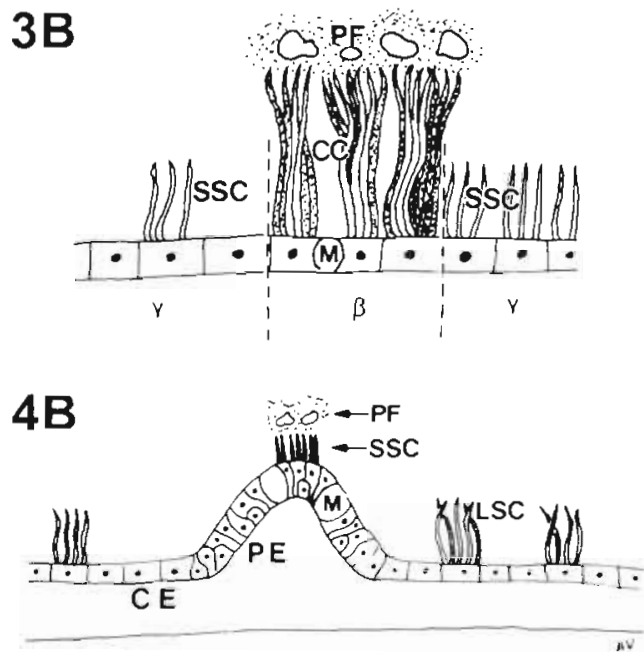

Crassotrea gigas

Fig. 4. Schematic drawings to compare the characteristics of Crassostrea spp. with those of species previously studied from the standpoint of pseudofeces transport and rejection (Beninger et al. 1999). (4.1-4.3) bivalves possessing a gill ventral particle groove and pallial siphons/apertures. (4.1A) Spisula solidissima. Three ciliary bands are arranged in a ventro-dorsal sequence: $\alpha$ : long composite cilia (rejection tract); $\beta$ : composite cilia; $\gamma$ : simple cilia. M: mantle. Arrows show direction of pseudofeces transport, dashed line shows plane of section for Fig. 1B. (4.1B) Cilia types of each band and transport of pseudofeces (PF) atop the LCC of the rejection tract. (4.2A) Mya arenaria. Two ciliary bands are found: $\beta$ (composite cilia: CC), and $\gamma$ (simple cilia: SC). Arrows show direction of pseudofeces transport, dashed line shows plane of section for Fig. 4.2B. (4.2B) Cilia types of each band and transport of pseudofeces atop the $\mathrm{CC}$ of the rejection tract. (4.3A) Mytius edulis. Three parallel ciliary bands extend dorsoventrally: short simple cilia ( $\gamma$ ), compound cilia $(\beta)$, and short simple cilia $(\gamma)$. Arrows show direction of pseudofeces transport, dashed line shows plane of section for Fig. 4.3B. (4.3B) Cilia types of each band, and transport of pseudofeces atop the CC of the rejection tract. (4.4A) Crassostrea virginica, C. gigas. Ciliated tracts of mantle pseudofeces rejection ridges, showing direction of pseudofeces transport (arrows). AM: adductor muscle; GJ: gill junction with mantle. Dashed line shows plane of section for Fig. 4.3B. (4.4B) Cilia types on mantle: short simple cilia (SSC) on rejection ridge, isolated tufts of long simple cilia (LSC) in interridge region. In all cases, pseudofeces are transported above the general pallial surface, either atop composite cilia longer than the cilia of the general pallial surface (Figs. 1-3), or atop short simple cilia, which are themselves elevated with respect to the general pallial surface via specialized rejection ridges (Fig. 4, Crassostrea spp.) 
The inter-ridge region presented a cuboidal epithelium almost devoid of cilia (Figs. 1.2, $1.3 \& 2.2-2.5$ ); however, occasional isolated tufts of LSC were observed (Fig. 1.6). No mucocytes were observed in the inter-ridge region in Masson's trichrome or PAS-alcian blue sections, which is indicative of their scarcity outside the pseudofeces rejection ridges.

In contrast to the complexity of the infrabranchial mantle surface, the suprabranchial mantle surface consisted of a dense, uniform cover of simple cilia punctuated only by occasional composite cilia (Fig. 1.7. 1.8). No ridges were observed on this surface.

Seawater suspensions of carmine and graphite particles placed directly on the mantle below the gillmantle junction of half-shell preparations were transported along radial tracts (which corresponded to the locations of the radial mantle ridges) to the mantle edge (Fig. 3.3A). A similar result could be observed when such suspensions were placed on the ridged surface of the labial palps; particles were first transported to the ventro-posterior apex of the palps and then deposited just below the gill-mantle junction. No such well-defined radial transport was observed when particles were placed on the suprabranchial mantle region.

\section{DISCUSSION}

\section{Role of the mantle ridges}

Previous microscopic studies of the mantle of bivalves have not surveyed the entire inner pallial surface in detail (see Beninger et al. 1999). The older literature (eg. Drew 1906, Kellogg 1915, Elsey 1935) seems to have sufficed for most workers. In the Bivalvia in general, and in the Ostreidae in particular, microscopical research has concentrated either on small pieces (Morrison 1993), or on the lobes at the mantle margins (Beninger \& Le Pennec 1991, Morrison 1993, Morse \& Zardus 1997). This situation may help explain why an anatomical feature so obvious as the mantle rejection ridges has rarely been alluded to in the literature. Ridges similar to those presented here have been reported in several oyster species, but their histological features and surface characteristics have not been extensively explored (Elsey 1935, Eble 1996, Eble \& Scro 1996). In contrast to these studies, we did not observe radial pallial nerves or haemolymph vessels within the mantle ridges. The present study shows that the mantle ridges are structures specialized in pseudofeces transport, whose heavilyciliated pseudostratified histological profile contrasts sharply with the sparsely-ciliated cuboidal epithelium of the inter-ridge region. Given the density of AMPS mucocytes on these ridges, and the scarcity of mucocytes in the inter-ridge region, pseudofeces transport is undoubtedly mucociliary in nature (see Lucas \& Douglas 1934, Silberberg et al. 1977, Yates et al. 1980, Blake \& Fulford 1984, Sleigh et al. 1988, Sleigh 1989, Beninger et al. 1997b) and confined to the ridges. The preponderance of AMPS mucocytes on the Crassostrea virginica 'ciliary tracts' is corroborated by Eble \& Scro (1996), who reported a ratio of 4 AMPS: 1 NMPS.

The radial configuration of the mantle ridges, fanning out from the adductor muscle region to the manthe periphery, may at first seem somewhat puzzling, since the labial palps do not extend posteriorly beyond the adductor muscle and hence cannot deposit pseudofeces beyond this point. However, under conditions of high particle load (frequently encountered in the coastal and estuarine oyster habitats), the mucusparticle cords may be ejected directly from the gill ventral particle groove at any point (Bernard 1974, Newell \& Langdon 1996), thus necessitating the presence of rejection pathways on the entire infrabranchial mantle surface.

\section{Oyster mantle ciliation and pallial currents}

The distal beating of the mantle rejection ridges obviously does not contribute to the general centripetal pallial flow; nor are the sparse tufts of LSC likely to contribute much to this flow. In the oyster, then, the dominant pallial flow must be maintained almost entirely by the gill and the abundant ciliation of the suprabranchial cavity. In this they resemble the Pectinidae, who share the monomyarian heterorhabdic filament condition and possess a sparsely-ciliated infrabranchial cavity (Beninger et al. 1999). This situation contrasts with that of the dimyarian homorhabdic condition, in which the infrabranchial mantle region is densely-ciliated, with a very discrete rejection tract (Beninger et al. 1999).

\section{How the oyster confirms the rule of mantle pseudofeces transport in bivalves}

In a previous study of species possessing the 3 other main bivalve gill types, the distinguishing feature of pseudofeces transport on the mantle was the vertical elevation of pseudofeces above the general pallial surface via specialized grouped cilia (composite cilia), which enabled pseudofeces transport to occur independently of the ciliary beating of the rest of the mantle surface (Beninger et al. 1999). Acid or aciddominant mucopolysaccharides appear to be the rule 
in mucociliary particle transport whenever it occurs on an exposed surface, especially when such transport is counter-current (Beninger \& St-Jean 1997b). Pseudofeces transport on the mantle surface shows both vertical elevation (specialized rejection ridges) and AMPS; the transport surface is exposed, and transport is counter-current (resultant of postero-anterior and ventro-dorsal vectors of dominant currents in the pallial cavity). To date, the oyster is the only bivalve studied in which composite cilia are not responsible for pseudofeces transport on the mantle; the overriding principle appears to be elevation above the general pallial surface rather than the use of a specific cilia type. However, AMPS are the transport medium in all species whose mantle histology has been studied to date (Ansell 1961, Eble \& Scro 1996, Beninger et al. 1999, present study).

The rule for bivalves with a gill ventral particle groove thus appears to be elevated mucociliary pseudofeces transport on the mantle. The types of cilia involved, and the position of the rejection tracts, are summarized in Fig. 4.

The Ostreidae thus consitute a distinct category from the standpoint of pseudofeces transport: although monomyarian, they do not void pseudofeces entirely via valve adduction, as in the Pectinidae. Instead, pseudofeces are transported by mucociliary means to the mantle margin, where relatively small valve adductions suffice to remove them (Galtsoff 1964).

We may thus summarize and revise to this point the pallial pseudofeces transport and rejection mechanisms in bivalves possessing the 4 main gill types: ciliary transport and AMPS, with vertical elevation accomplished by composite cilia (Category 1-homorhabdic filibranchs and eulamellibranchs), ciliary transport and AMPS, with vertical elevation accomplished by radial mantle ridges (Category 2-pseudolamellibranchs), and voidance via valve clapping (Category 3-heterorhabdic filibranchs).

The results of the present and previous studies involving mucocyte and cilia mapping in bivalves (Beninger et al. 1995, 1999, Beninger \& St-Jean 1997b) point to an intriguing conclusion: the performance of the very complex task of particle processing must be carried out using a combination of the only 3 levels of specialization available to this life form: topological (the architecture of the pallial organs), microstructural (the cilia types) and biochemical (the mucocyte types). Although we now have some understanding of the contribution of the topological level (e.g. Beninger et al. 1992, 1997a, Tankersley \& Dimock 1993, Ward et al. 1993, 1994, 1998, Tankersley 1996), including the rejection ridges of the present study, our understanding of the other levels remains limited. Some progress has been made in the study of cilia types and functions (Owen \& McCrae 1976, Owen 1978, Beninger et al. 1995, 1997b, 1999, Silverman et al. 1996, Beninger et al. 1997b), but the understanding of mucocyte specialisation is still rudimentary (Beninger et al. 1993, 1997a, Beninger \& Le Pennec 1993, Beninger \& Dufour 1996, Beninger \& St-Jean 1997b, Davies \& Hawkins 1998); in particular, the correspondence between histochemical and ultrastructural characteristics is unknown-doubtless imposing limitations on our understanding of the system as a whole.

Although considerable advances have been made in the field of particle processing over the past decade, progress is painstaking, and requires multiple approaches and techniques corresponding to the multiple scales involved. The present study underscores the particular importance of detailed investigations of the cellular specializations which are the underlying effectors of particle processing in bivalves.

Acknowledgements. We thank Mr F. Hennequart for assistance with histological preparations, Mr R. Pajot for supplying the specimens of Crassostrea gigas, Mr L. Blanchard and C. Riquier for photographic services, and Dr L. Barillé for comments and critique prior to submission. This work was funded in part by an operating grant from the Natural Sciences and Engineering Research Council (Canada) to P.G.B.

\section{LITERATURE CITED}

Ansell AD (1961) The functional morphology of the British species of Veneracea (Eulamellibranchia). J Mar Biol Assoc UK 41:489-515

Atkins D (1936) On the ciliary mechanisms and interrelationships of lamellibranchs. Part I. Some new observations on sorting mechanisms in certain lamellibranchs. Q J Microsc Sci 79:181-308

Atkins D (1937a) On the ciliary mechanisms and interrelationships of lamellibranchs. Part II. Sorting devices on the gills. Q J Microsc Sci 79:339-373

Atkins $D(1937 b)$ On the ciliary mechanisms and interrelationships of lamellibranchs. Part III. Types of lamellibranch gills and their food currents. Q J Microsc Sci 79 : $375-421$

Atkins D (1938) On the ciliary mechanisms and interrelationships of lamellibranchia. Part VII. Latero-frontal cilia of the gill filaments and their phylogenetic value. $Q \mathrm{~J}$ Microsc Sci 80:345-436

Beninger PG, Dufour SC (1996) Mucocyte distribution and relationship to particle transport on the pseudolamellibranch gill of Crassostrea virginica (Bivalvia: Ostreidae). Mar Ecol Prog Ser 137:133-138

Beninger PG, Le Pennec M (1991) Functional anatomy of scallops. In: Shumway SE (ed) Scallops: biology, ecology, and aquaculture. Elsevier, Amsterdam, p 133-223

Beninger PG, Le Pennec M (1993) Histochemistry of the buccooesophageal glands of Mytilus edulis: the importance of mucus in ingestion. J Mar Biol Assoc UK 73:237-240

Beninger PG, St-Jean SD (1997a) Particle processing on the labial palps of Mytilus edulis and Placopecten magellanicus (Mollusca: Bivalvia). Mar Ecol Prog Ser 147:117-127 
Beninger PG, St-Jean SD (1997b) The role of mucus in particle processing by suspension-feeding marine bivalves: unifying principles. Mar Biol 129:389-397

Beninger PG, Ward JE, MacDonald BA, Thompson RJ (1992) Gill function and particle transport in Placopecten magellanicus (Mollusca: Bivalvia) as revealed using video endoscopy. Mar Biol 114:281-288

Beninger PG. St-Jean S, Poussart Y, Ward JE (1993) Gill function and mucocyte distribution in Placopecten magellanicus and Mytilus edulis (Mollusca: Bivalvia): the role of mucus in particle transport. Mar Ecol Prog Ser 98:275-282

Beninger PG. Potter TM, St-Jean SD (1995a) Paddle cilia fixation artefacts in pallial organs of adult Mytilus edulis and Placopecten magellanicus (Mollusca, Bivalvia). Can J Zool 73:610-614

Beninger PG, St-Jean SD, Poussart Y (1995b) Labial palps of the blue mussel Mytilus edulis (Bivalvia: Mytilıdae). Mar Biol 123:293-303

Beninger PG, Dufour SC, Bourque J (1997a) Particle processing mechanisms of the eulamellibranch bivalves Spisula solidissima and Mya arenaria. Mar Ecol Prog Ser 150: $157-169$

Beninger PG, Lynn JW, Dietz TH, Silverman H (1997b) Mucociliary transport in living tissue: the two-layer model confirmed in the mussel Mytilus edulis L. Biol Bull 193:4-7

Beninger PG, Veniot A, Poussart X (1999) Principles of pseudofeces rejection on the bivalve mantle: integration in particle processing. Mar Ecol Prog Ser 178:259-269

Bernard FR (1974) Particle sorting and labial palp function in the Pacific oyster Crassostrea gigas (Thunberg, 1795). Biol Bull 146:1-10

Blake JR, Fulford GR (1984) Mechanics of ciliary transport Physico Chem Hyd 5:401-411

Davies MS, Hawkins SJ (1988) Mucus from marine molluscs. Adv Mar Biol 34:1-71

Drew GA (1906) The habits, anatomy, and embryology of the giant scallop (Pecten tenuicostatus, Mighels). Univ Maine Studies Ser 6:1-89

Eble AF (1996) The circulatory system. In: Kennedy VS, Newell RIE, Eble AF (eds) The Eastern oyster Crassostrea virginica. Maryland Sea Grant College Publishers, College Park, MD, p 271-298

Eble AF, Scro R (1996) General anatomy. In: Kennedy VS, Newell RIE, Eble AF (eds) The Eastern oyster Crassostrea virginica. Maryland Sea Grant College Publishers, College Park, MD, p 19-73

Elsey CR (1935) On the structure and function of the mantle and gill of Ostrea gigas (Thunberg) and Ostrea lurida (Carpenter). Trans R Soc Can 29 (Sec V):131-158 + 5 pl

Galtsoff PS (1964) The American oyster Crassostrea virginica Gmelin. Fish Bull 64:1-480

Jørgensen CB (1990) Bivalve filter feeding: hydrodynamics, bioenergetics, physiology and ecology. Olsen \& Olsen, Helstedsverj, p 1-140

Kellogg JL (1915) Ciliary mechanisms of lamellibranchs with descriptions of anatomy. J Morph 26:625-701

Lucas AM, Douglas LC (1934) Principles underlying ciliary activity in the respiratory tract II. A comparision of nasal clearance in man, monkey, and other mammals. Arch Otolaryngol 20:518-541

Moore HJ (1971) The structure of the latero-frontal cirri on the gills of certain lamellibranch molluscs and their role in suspension-feeding. Mar Biol 11:23-27

Morrison CM (1993) Histology and cell ultrastructure of the mantle and mantle lobes of the Eastern oyster, Crassostrea virginica (Gmelin): a summary atlas. Am Malacol Bull 10: $1-24$
Morse MP, Zardus JD (1997) Bivalvia. In: Harrison FW, Kohn AJ (eds) Microscopic anatomy of invertebrates. WileyLiss, New York, p 7-118

Morton B (1979) A comparison of lip structure and function correlated with other aspects of the functional morphology of Lima lima, Limaria (Platilimaria) fragilis, and Limaria (Platilimaria) hongkongensis sp. nov. (Bivalvia: Limaceae). Can J Zool 57:728-742

Newell RIE, Langdon CJ (1996) Mechanisms and physiology of larval and adult feeding. In: Kennedy VS, Newell RIE, Eble AF (eds) The Eastern oyster Crassostrea virginica. Maryland Sea Grant College Publishers, College Park, MD, p 185-229

Orton $\mathrm{JH}$ (1912) The mode of feeding of Crepidula, with an account of the current-producing mechanism in the mantle cavity, and some remarks on the mode of feeding in Gastropods and Lamellibranchs. J Mar Biol Assoc UK $9: 444-478$

Owen G (1974) Studies on the gill of Mytilus edulis: the eulatero-frontal cirni. Proc R Soc Lond B 187:83-91

Owen G (1978) Classification and the bivalve gill. Phil Trans Roy Soc Lond B 284:377-385

Owen G, McCrae JM (1976) Further studies on the laterofrontal tracts of bivalves. Proc R Soc Lond B 194 : $527-544$

Peek K, Gabbott PA (1990) Seasonal cycle of lysosomal enzyme activities in the mantle tissue and isolated cells from the mussel Mytilus edulis. Mar Biol 104:403-412

Ribelin RW, Collier A (1977) Studies on the gill ciliation of the American Oyster Crassostrea virginica (Gmelin). J Morphol 151:439-449

Saleuddin ASM, Petit H (1983) The mode of formation of the periostracum. In: Saleuddin ASM, Wilbur KM (eds) The Mollusca, Vol 4. Physiology, Part 1. Academic Press, New York, p 199-234

Silberberg A, Meyer FA, Gilboa A, Gelman RA (1977) Function and properties of epithelial mucus. In: Epstein $M$, Parke OV (eds) Advances in experimental medicine and biology 89. Plenum Press, New York, p 171-180

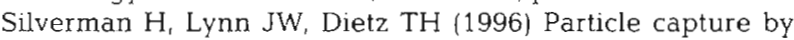
the gills of Dreissena polymorpha: structure and function of latero-frontal cirri. Biol Bull 191:42-54

Sleigh MS (1989) Adaptations of ciliary systems for the propulsion of water and mucus. Comp Biochem Physiol 94(A): $359-364$

Sleigh MS, Blake JR, Liron N (1988) The propulsion of mucus by cilia. Am Rev Resp Dis 137:726-741

Tankersley RA (1996) Multipurpose gills: effect of larval brooding on the feeding physiology of freshwater unionid mussels. Invert Biol 115:243-255

Tankersley RA, Dimock RV Jr (1993) Endoscopic visualization of the functional morphology of the ctenidia of the unionid mussel Pyganodon cataracta. Can J Zool 71:811-819

Wallengren $H$ (1905) Zur Biologie der Muscheln. II. Die Nahrungsaufnahme. Kongl Fysiografiska Sälskapets Hand NF 16:1-59

Waller TR (1976) The behavior and tentacle morphology of pteridiomorphian bivalves: a motion picture study. Bull Am Malacol Union 1976:7-13

Ward JE, MacDonald BA, Thompson RJ, Beninger PG (1993) Mechanisms of suspension-feeding in bivalves: resolution of current controversies by means of endoscopy. Limnol Oceanogr 38:265-272

Ward JE, Newell RIE, Thompson RJ, MacDonald BA (1994) In vivo studies of suspension-feeding processes in the eastern oyster, Crassostrea virginica (Gmelin). Biol Bull $186: 221-240$ 
Ward JE, Levinton JS, Shumway SE, Cucci T (1998) Particle sorting in bivalves: in vivo determination of the pallial organs of selection. Mar Biol 131:283-292

Wilbur KM (1972) Shell formation in molluscs. In: Florkin M, Scheer BT (eds) Chemical Zoology VII: Mollusca. Academic Press, New York, p 243-282

Wilbur KM (1985) Topics in molluscan mineralization: present status, future directions. Am Malacol Union Bull Special Edition 1:51-58

Editorial responsibility: Otto Kinne (Editor),

Oldendorf/Luhe, Germany
Wilbur KM, Saleuddin ASM (1983) Shell formation. In: Saleuddin ASM, Wilbur KM (eds) The Mollusca, Vol 4. Physiology, Part 1. Academic Press, New York, p 235-287

Yates GT, Wu TY, Johnson RE, Cheung ATW, Frand CL (1980) A theoretical and experimental study on tracheal muco-ciliary transport. Biorheology 17:151-162

Yonge CM (1967) Observations on Pedum spondyloideum (Chemnitz) Gmelin, a scallop associated with reef-building corals. Proc Malacol Soc Lond 37:311-323

Submitted: January 19, 1999; Accepted: June 30, 1999

Proofs received from author(s): November 17, 1999 